\title{
Morphology in Hematology
}

\section{Aggressive Multiple Myeloma with Unusual Morphology Olağan Dışı Morfoloji ile Multipl Miyelom}

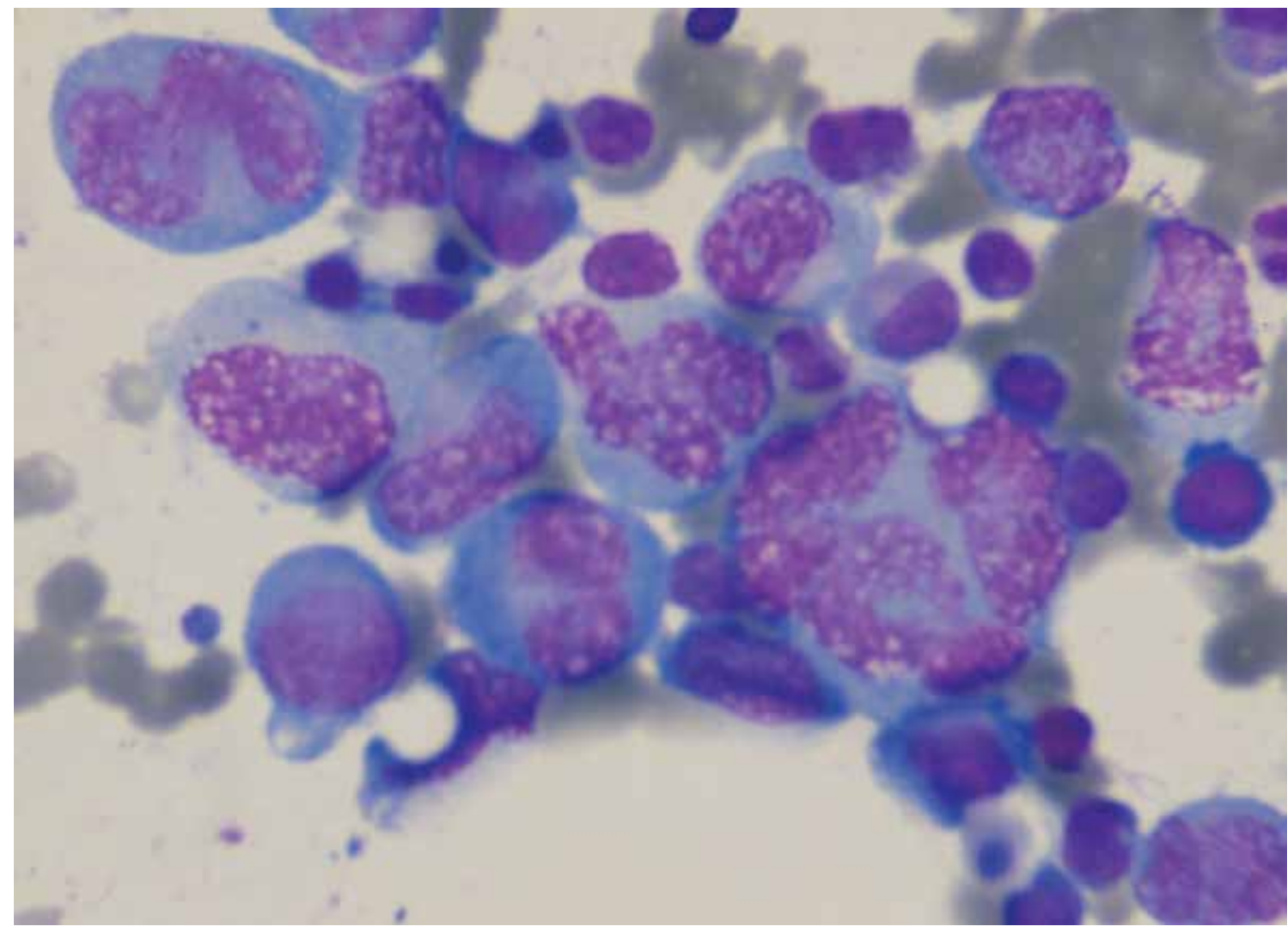

Figure 1. Atypical and multinucleated plasma cell infiltration in the bone marrow aspirate (Wright's stain, 100x).

A 66-year-old male patient was admitted to the hospital with backache, fatigue, and paraesthesia and spasm in both legs. He had lower extremity numbness and bladder and bowel incontinence. Physical examination revealed the absence of bilateral lower extremity reflexes and lower extremity weakness. Magnetic resonance imaging showed a large mass extending from T8 to T9, fracture of T9, and compression of the spinal cord. Informed consent was obtained.

Laboratory results at initial evaluation revealed the following: haemoglobin: $118 \mathrm{~g} / \mathrm{L}$, haematocrit: $33.5 \%$, white blood cell count: $6.7 \times 109 / \mathrm{L}$, platelets: $192 \times 109 / \mathrm{L}$, blood urea nitrogen: $7.5 \mathrm{mmol} / \mathrm{L}$, creatinine: $113.1 \mu \mathrm{mol} / \mathrm{L}$, calcium: $1.9 \mathrm{mmol} / \mathrm{L}$, total protein: $63 \mathrm{~g} / \mathrm{L}$; albumin: $31 \mathrm{~g} / \mathrm{L}$; and erythrocyte sedimentation rate: $59 \mathrm{~mm} / \mathrm{h}$. Protein studies by nephelometry revealed IgA of $4.25 \mathrm{~g} / \mathrm{L}$ (reference range: $0.7-4 \mathrm{~g} / \mathrm{L}$ ) and lambda light chain of $3.98 \mathrm{~g} / \mathrm{L}$ (reference range: $0.9-2.1 \mathrm{~g} / \mathrm{L}$ ). A small monoclonal spike was present upon protein electrophoresis. Urine immunoelectrophoresis documented no monoclonal light chain. Bone marrow aspirate and biopsy were performed and the patient underwent surgical decompression and stabilisation of the thoracic spine. The bone marrow aspirate and biopsy morphology showed infiltration with atypical, multilobated, cleaved, and monocytoid nuclei plasma cells (Figures 1 and 2). The biopsy material stained positive with lambda light chain and CD138. 


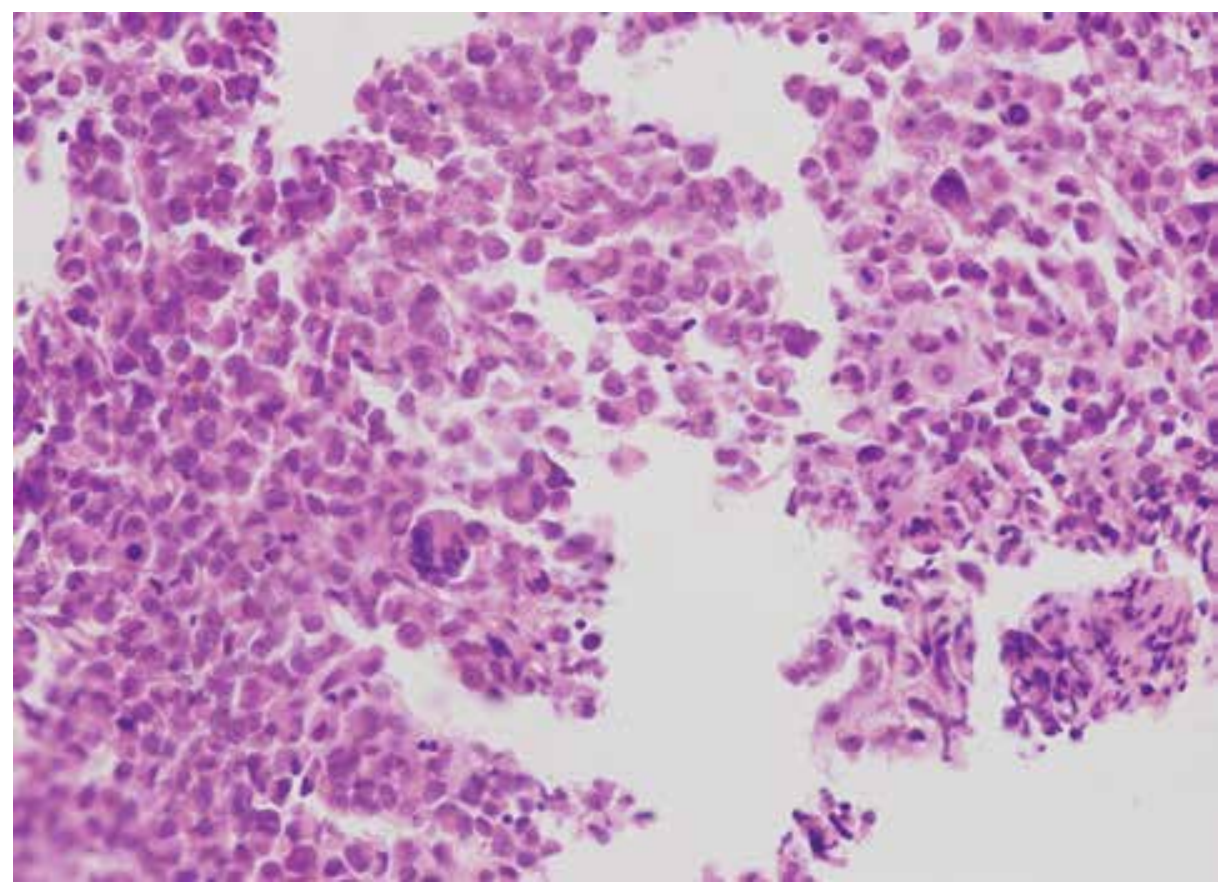

Figure 2. Atypical and multinucleated plasma cell infiltration in the bone marrow biopsy (H\&E, 20x).

The neoplastic plasma cells exhibit a variety of morphologies. Poorly differentiated plasma cells may show atypical morphology, making it difficult to recognise their plasma cell nature. Plasma cell morphology correlates with disease course, prognosis, and resistance to conventional treatment $[1,2,3]$.

\section{Conflict of Interest Statement}

The authors of this paper have no conflicts of interest, including specific financial interests, relationships, and/or affiliations relevant to the subject matter or materials included.

Key Words: Multiple myeloma, Unusual morphology

Anahtar Sözcükler: Multipl miyelom, Olağan dışı morfoloji

\section{Mehmet Sönmez¹, Hasan Mücahit Özbaş¹, Nilay Ermantaş', Ümit Çobanoğlu²}

1Karadeniz Technical University Faculty of Medicine, Department of Hematology, Trabzon, Turkey

2Karadeniz Technical University Faculty of Medicine, Department of Pathology, Trabzon, Turkey

Phone: +90 4623775848 E-mail: mesonmez@yahoo.com

Received/Geliş tarihi : March 20, 2013

Accepted/Kabul tarihi : April 25, 2013

\section{References}

1. Stifter S, Babarovic E, Valkovic T, Seili-Bekafigo I, Stemberger C, Nacinovic A, Lucin K, Jonjic N. Combined evaluation of bone marrow aspirate and biopsy is superior in the prognosis of multiple myeloma. Diagn Pathol 2010;5:30.

2. Kyle RA, Rajkumar SV. Criteria for diagnosis, staging, risk stratification and response assessment of multiple myeloma. Leukemia 2009;23:3-9.

3. Erkut N, Çobanoğlu Ü, Sönmez M. Multiple myeloma with multilobated plasma cell nuclei. Turk J Hematol 2011;28:158159. 